\title{
IAIN Sorong dan Momentum Setelah Pandemi Korona
}

\author{
Ismail Suardi Wekke \\ Institut Agama Islam Negeri (IAIN) Sorong \\ Email: iswekke@gmail.com
}

"malang tak dapat ditolak, untung tidak dapat diraih"

Itu pepatah yang menggambarkan situasi yang tidak dapat kita kontrol.

Demikian pula pandemi Korona. Menyebar dan bahkan menjadi pemicu kematian. Berita baiknya, Jumat 20 Maret 2020, Satgas Penanganan Korona menyatakan sudah ada 17 penyintas Korona yang sembuh.

Apa yang dapat kita lakukan dengan pandemi ini?

Pertama, menyiapkan perangkat pembelajaran daring. Bahkan satu ruangan dikhususkan untuk teleconference.

Perangkat ini, diperlukan yang ready-to-use. Dengan kemampuan minimal dalam pengoprasian peralatan IT, bisa digunakan.

Bukan perangkat yang kompleks sehingga memerlukan laboran atau teknisi.

Ini bisa disiapkan dengan melakukan benchmark ataupun menggunakan konsultan perencana khusus untuk keperluan IT.

Bukan laboratorium mengada-ada, seperti laboratorium dakwah. Itu sepenuhnya tidak perlu diadakan, karena soal dakwah ada keperluan lain, seperti televisi, radio, ataupun percetakan.

Kedua, penyamaan persepsi tentang pembelajaran daring. Dosen dilatih dan disamakan persepsinya terkait pembelajaran daring. Beragam pilihan perangkat lunak, perlu dipilih salah satunya kemudian digunakan Bersama.

Sehingga, mahasiswa hanya akan menggunakan satu platform. Tidak berpindah-pindah dari satu platform ke platform lainnya karena berbeda pilihan antar dosen.

Terakhir, sudah diperlukan ruang belajar yang menampung mahasiswa sampai 100 orang. Ruang belajar dalam bentuk kursi yang permanen, whiteboard dengan teknologi yang paling mutakhir dan bisa merekam (dengan catatan friendly user), bisajadi ini juga dilengkapi dengan teleconference, paling utama adalah genset yang bisa berfungsi otomatis. Begitu aliran listrik PLN terputus, dalam hitungan detik langsung berfungsi. 